\title{
EFFECT OF PNEUMOPERITONEUM IN MODEL OF ABDOMINAL SEPSIS
}

\section{EFEITO DO PNEUMOPERITÔNEO EM MODELO DE SEPSE ABDOMINAL}

Cybelle Dutra da Silva ${ }^{1}$, Evelynne Mayara de Araújo Silva ${ }^{1}$, Vítor Brasil Medeiros ${ }^{2}$, Aldo Cunha Medeiros ${ }^{3}$

1. Graduate student, Medical School, Federal University of Rio Grande do Norte (UFRN), Natal-RN, Brazil.

2. Veterinarian, Natal-RN, Brazil.

3. PhD, Full Professor, Chairman, Nucleus of Experimental Surgery, UFRN, Natal-RN, Brazil.

This research was made at the Department of Surgery from Federal University of Rio Grande do Norte (UFRN), Brazil.

Financial support: None.

Conflicts of interest: None.

Address for correspondence: Department of Surgery, Federal University of do Rio

Grande do Norte, Ave. Nilo Peçanha 620, Natal, RN, Brazil.

E-mail: cirurgex.ufrn@gmail.com

Submitted: may 12; accepted after revision, may 12, 2020.

\section{ABSTRACT}

Purpose: This study aims to examine the effects of $\mathrm{CO}_{2}$ pneumoperitoneum on the level of inflammation biomarkers in a model of abdominal sepsis in rats. Methods: Twelve Wistar rats were randomly assigned to two groups of 6 rats each. Under anesthesia, abdominal sepsis was induced by cecal ligation and puncture (CLP). Rats were observed for 24 hours. Group 1: sepsis; group 2: sepsis + pneumoperitoneum with $\mathrm{CO}_{2}$ for $30 \mathrm{~min}$. Six hours after pneumoperitoneum deflation, blood samples were collected by cardiac

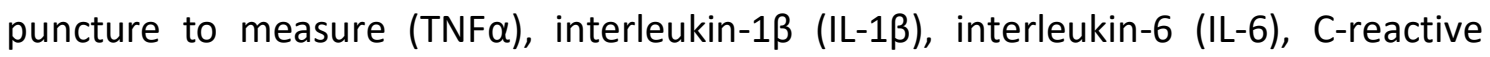
protein (CRP) and procalcitonin (PCT). Statistical analysis using Student t test $(p<0.05)$. Results: All animals survived. The rats with sepsis + pneumoperitoneum had levels of TNF $\alpha, I L-1 \beta$ and IL-6 $(542.4 \pm 21 \mathrm{pg} / \mathrm{mL}, 312.1 \pm 12 \mathrm{pg} / \mathrm{mL}$ and $115.4 \pm 11 \mathrm{pg} / \mathrm{mL}$, respectively), significantly lower than in the sepsis group $(p=0.01)$. Serum cytokine levels in the sepsis group were TNF $\alpha=733.2 \pm 24 \mathrm{p} / \mathrm{mL}$; IL-1 $\beta=432.1 \pm 15 \mathrm{pg} / \mathrm{mL}$ and IL-6 = $232.3 \pm 16 \mathrm{pg} / \mathrm{mL}$. Serum levels of PCT and CRP were significantly lower in the sepsis + pneumoperitoneum group than in the sepsis group. $(p=0.01)$. Conclusion: In conclusion, pneumoperitoneum $\mathrm{CO} 2$ attenuates the biomarkers of the acute phase inflammatory response associated with perioperative sepsis by PLC.

Key words: Sepsis. Pneumoperitoneum. Cytokines. Procalcitonin. C-reactive protein. Inflammation. 


\section{RESUMO:}

Objetivo: Este estudo tem como objetivo examinar os efeitos do pneumoperitônio de CO2 no nível de biomarcadores de inflamação em um modelo de sepse abdominal em ratos. Métodos: Doze ratos Wistar foram distribuídos aleatoriamente em dois grupos de 6 ratos cada. Sob anestesia, em todos os animais foi induzida sepse abdominal por ligadura e punção do ceco (LPC). Os ratos foram observados por 24 horas. Grupo 1: LPC sepse; grupo 2: sepse + pneumoperitônio com $\mathrm{CO}_{2}$ por $30 \mathrm{~min}$. Seis horas após a desinsuflação do pneumoperitôneo, amostras de sangue foram coletadas por punção cardíaca para dosagem de (TNF $\alpha$ ), interleucina-1 $\beta$ (IL-1 $\beta$ ), interleucina-6 (IL-6), proteína $C$ reativa (PCR) e procalcitonina (PCT). Análise estatística pelo teste de Student $(p<0,05)$. Resultados: Todos os animais sobreviveram. Os ratos com sepse + pneumoperitôneo com $\mathrm{CO}_{2}$ tiveram níveis de TNF $\alpha$, IL-1 $\beta$ e IL-6 $(542,4 \pm 21 \mathrm{pg} / \mathrm{mL} ; 312,1 \pm 12 \mathrm{pg} / \mathrm{mL}$ e $115,4 \pm 11 \mathrm{pg} / \mathrm{mL}$, respectivamente), significativamente mais baixos que no grupo sepse $(p=0,01)$. As dosagens séricas das citocinas no grupo sepse foram TNF $\alpha=733,2 \pm 24$ $\mathrm{pg} / \mathrm{mL}$; IL-1 $\beta=432,1 \pm 15 \mathrm{pg} / \mathrm{mL}$ e IL-6=232,3 $\pm 16 \mathrm{pg} / \mathrm{mL}$. Os níveis séricos de PCT e PCR foram significativamente mais baixos no grupo sepse + pneumoperitôneo que no grupo sepse. $(p=0,01)$. Conclusão: Em conclusão, o pneumoperitônio de CO2 atenua os biomarcadores da resposta inflamatória de fase aguda associada à sepse peri-operatória por CLP.

Descritores: Sepse. Pneumoperitôneo. Citocinas. Procalcitonina. Proteína C reativa. Inflamação.

\section{INTRODUCTION}

Sepsis is defined as a life-threatening organ dysfunction that occurs due to a dysregulated host response to infection ${ }^{1}$. Sepsis is one of the most common causes of ICU hospitalization, and its frequency continues to increase ${ }^{2}$. Several studies have shown that mortality related to sepsis has been decreasing annually, but in low and middleincome countries there is still a high mortality rate that can be up to $80 \%$. Patients at risk of sepsis should be identified prior to the onset of organ dysfunction and they require rapid diagnosis and onset of treatment ${ }^{1}$. The immune system harbors humoral, cellular, and neural mechanisms that attenuate the potentially harmful effects of the proinflammatory response ${ }^{3}$. Phagocytes can switch to an antiinflammatory phenotype that promotes tissue repair, and regulatory T cells and myeloidderived suppressor cells further reduce inflammation. In addition, neural mechanisms can inhibit inflammation. In animal models of sepsis ${ }^{4}$, disruption of this neural-based system by vagotomy increases susceptibility to endotoxin shock, whereas stimulation of the efferent vagus nerve or $\alpha 7$ cholinergic receptors attenuates systemic inflammation ${ }^{5}$. Some patients frequently have ongoing infectious foci, despite antimicrobial therapy ${ }^{6}$. Multiple studies have documented reduced responsiveness of blood leukocytes to pathogens in patients with sepsis ${ }^{3}$, findings that were recently corroborated by postmortem studies revealing 
Effect of pneumoperitoneum in model of abdominal sepsis

Silva $C D$, et al

strong functional impairments of splenocytes obtained from patients who had died of sepsis in the ICU. Besides the spleen, the lungs also showed evidence of immunosuppression ${ }^{5,6}$.

In the activated innate immune response to sepsis, pro-inflammatory and antiinflammatory mediators such as tumor necrosis factor- $\alpha$ (TNF- $\alpha$ ), interleukin-1 $\beta$ (IL-1 $\beta$ ), interleukin-6 (IL-6) and monocyte chemoattractant protein 1 (MCP-1) are released, followed a rise in the levels of acute phase proteins such as procalcitonin and $\mathrm{C}$-reactive protein $^{7,8}$

Several experimental evidences suggest that $\mathrm{CO}_{2}$ pneumoperitoneum reduces the severity of sepsis and prolongs survival, compared with laparotomy in animal models of abdominal sepsis ${ }^{9-11}$. However, little is known about the $\mathrm{CO}_{2}$ pneumoperitoneum impact on early acute phase response in sepsis and respective biomarkers. Some experimental models have been successful in the study of abdominal sepsis ${ }^{12-14}$. Considering these knowledges, we performed this study, with the objective of examine the effects of $\mathrm{CO}_{2}$ pneumoperitoneum on the level of inflammation markers and survival in a rat model of abdominal sepsis.

\section{METHODS}

Wistar rats (Rattus norvegicus) 3 to 4 months old were used, from the Vivarium of the Health Sciences Center of the Federal University of Rio Grande do Norte. The protocol was submitted for appreciation and approved by the HUOL Animal Use Ethics Committee (CEUA / HUOL) in accordance with protocol No. 03/2019. The Wistar rats were kept in individual polypropylene cages with $12 \mathrm{~h}$ light-dark cycles. They went through a 7-day acclimatization period at the Experimental Surgery Center-UFRN, with ad libitum access to water and food for rats (Presence ${ }^{\circledR}$ ). The care in the use of animals followed the rules of the Brazilian Legislation for the scientific use of animals (Law no 11.794 / 2008).

\section{Animals and groups}

The rats were anesthetized with intraperitoneal injection of ketamine $70 \mathrm{mg} / \mathrm{kg}$ and xylazine $7 \mathrm{mg} / \mathrm{kg}$. After epilation and antisepsis of the abdomen with $70 \%$ alcohol, ligation and puncture of the cecum was performed in all animals.

\section{Experimental design}

Twelve rats were randomly assigned to two groups of 6 rats each.

Group 1: sepsis group. In all animals, abdominal sepsis was done by cecal ligation and puncture. After anesthesia and aseptic procedures with $70 \%$ ethanol, a $4 \mathrm{~cm}$ laparotomy was performed. The cecum was exposed, ligated with sterile 2-0 cotton and four punctures were made with a 25 gauge needle. A small amount of fecal material was 
Effect of pneumoperitoneum in model of abdominal sepsis

Silva $C D$, et al

extruded through the punctures, and the cecum was pushed into the abdomen. The abdominal wall was sutured with nylon 4-0 (Ethicon) in two layers. All rats received volemic reposition of $5 \mathrm{~mL}$ of sterile saline subcutaneously.

Group 2: sepsis + pneumoperitoneum (30 min)

Sixteen hours after $\mathrm{CPL}$, a $\mathrm{CO}_{2}$ pneumoperitoneum was created using a Veress needle connected to a pressurized container. $\mathrm{CO}_{2}$ was insufflated into the peritoneal cavity using an automatic insufflator (Edlo, RS, Brazil) until the intra-abdominal pressure stabilized at $10 \mathrm{mmHg}$. The pneumoperitoneum was maintained for $30 \mathrm{~min}$, after which the needle was removed and the abdomen was deflated. All surgical procedures were performed using aseptic technique.

\section{Biochemical analysis}

Six hours after pneumoperitoneum deflation, the surviving rats were anesthetized with ketamine $(70 \mathrm{mg} / \mathrm{kg})+$ xylazine $(7 \mathrm{mg} / \mathrm{kg})$ i.p. Blood samples were collected by cardiac puncture and centrifuged at $3500 \mathrm{rpm}$ for $10 \mathrm{~min}$ and the serum was stored at $-20^{\circ} \mathrm{C}$ until analysis. Then the rats were euthanized with overdose of thiopental (100 mg/kg i.p.).

The following dosages were processed: tumor necrosis factor-alpha (TNF $\alpha$ ), interleukin-1 $\beta$ (IL-1 $\beta$ ) and interleukin-6 (IL-6), using the ELISA technique with kits from PeproTech, Rocky Hill, NJ, USA, according to the manufacturer's recommended protocols. Fluorescence was measured using the Bio-Tec Instruments EL 808 microplate reader, using the KC4-V3.0 software. The detection sensitivity was $20 \mathrm{pg} / \mathrm{ml}$ for cytokines. The serum concentration of procalcitonin (PCT) was determined in duplicate using an immunoluminometric assay (Brahms, PCT-LIA, Berlin, Germany). The lowest concentration of PCT detectable by this technique was $0.08 \mathrm{ng} / \mathrm{mL}$ and the reference value established by the method was $<0.5 \mathrm{ng} / \mathrm{mL}$. C-reactive protein (CRP) was measured by immunoturbidimetry, using the Orion Diagnostica equipment (OY, Finland), and the reference value established by the method was 0 to $3 \mathrm{mg} / \mathrm{L}$.

\section{Statistical analysis}

All values were expressed as mean \pm standard deviation. The analyzes were performed using the Student's t-test and the $p$-value $<0.05$ was considered statistically significant. Statistical determinations were performed using the BioEstat 5.0 software.

\section{RESULTS}

All animals survived the experiments until the end of the observation period.

Rats with sepsis associated with $\mathrm{CO}_{2}$ pneumoperitoneum had levels of TNF $\alpha$, IL$1 \beta$ and IL-6 (542.4 $\pm 21 \mathrm{pg} / \mathrm{mL} ; 312.1 \pm 12 \mathrm{pg} / \mathrm{mL}$ and $115.4 \pm 11 \mathrm{pg} / \mathrm{mL}$ respectively) lower than the animals submitted only to $\mathrm{CPL}$; the difference was statistically significant 
Effect of pneumoperitoneum in model of abdominal sepsis

Silva $C D$, et al

$(p=0.01)$. The serum dosages of cytokines in the sepsis group were, (TNF $\alpha=733.2 \pm 24$ $\mathrm{pg} / \mathrm{mL} ; \mathrm{IL}-1 \beta=432.1 \pm 15 \mathrm{pg} / \mathrm{mL}$ and IL-6 $=232.3 \pm 16 \mathrm{pg} / \mathrm{mL}$. Data summarized in table 1.

Table 1 - Cytokine dosage values of rats with abdominal sepsis associated or not with $\mathrm{CO}_{2}$ pneumoperitoneum.

\begin{tabular}{cccc}
\hline Cytokines & Sepsis + pneumoperitoneum & Sepsis & P-value \\
\hline TNF $\alpha(\mathrm{pg} / \mathrm{ml})$ & $532.4 \pm 21$ & $733.2 \pm 24$ & 0.01 \\
$\mathrm{IL}-1 \beta(\mathrm{pg} / \mathrm{mL})$ & $312.1 \pm 12$ & $432.1 \pm 15$ & 0.01 \\
$\mathrm{IL}-6(\mathrm{pg} / \mathrm{mL})$ & $115.4 \pm 11$ & $232.3 \pm 16$ & 0.01 \\
\hline
\end{tabular}

Cytokine dosages differ significantly between groups ( $p=0.01$, Student's t-test).

Serum levels of procalcitonin (PCT) were significantly lower in septic animals with pneumoperitoneum, compared with animals with only sepsis, as can be seen in Table 2 . The levels of C-reactive protein (CRP) followed the same interpretation PCT, that is, rats with sepsis and pneumoperitoneum had significantly lower serum CRP levels than animals submitted to PLC alone $(p=0.01)$. Data summarized in table 2 .

Table 2 - Values of procalcitonin and C-reactive protein in rats with abdominal sepsis associated or not with $\mathrm{CO}_{2}$ pneumoperitoneum.

\begin{tabular}{lccc}
\hline $\begin{array}{c}\text { Acute phase } \\
\text { proteins }\end{array}$ & Sepsis + pneumoperitoneum & Sepsis & P-value \\
\hline PCT $(\mathrm{ng} / \mathrm{ml})$ & $4.2 \pm 1.3$ & $7.8 \pm 1.4$ & 0.01 \\
$\mathrm{CRP}(\mathrm{mg} / \mathrm{L})$ & $13.1 \pm 1.1$ & $19.7 \pm 1.5$ & 0.01 \\
\hline
\end{tabular}

CRP, C-reactive protein; PCT, procalcitonin. CRP and PCT dosages differ significantly between groups (Student's t-test).

\section{DISCUSSION}

The major pathophysiological mechanism accounting for the development and progression of sepsis is the dysregulation of dynamic balance between inflammatory mediators and anti-inflammatory factors ${ }^{15}$. Infection, without early treatment, usually leads to severe persistent hypotension, and affects the physiological functions of multiple organs, contributing to the septic shock and multiple organ dysfunction syndrome, with high mortality ${ }^{16,17}$.

With regard to cytokines, TNF- $\alpha$ is released first, and can activate signal to induce the secretion of pro-inflammatory IL-1 $\beta$ and IL- 6 cytokines, and inhibit the antiinflammatory factors, acting to trigger the release of inflammatory cascade ${ }^{18}$.

PCT is a sepsis marker prohormone, which represents the precursor to calcitonin. Serves as an indicator with a high value in monitoring sepsis in clinical practice ${ }^{19}$. Sepsis 
Effect of pneumoperitoneum in model of abdominal sepsis

Silva $C D$, et al

is always associated with an acute increase in PCT. Generally, a few hours after infection, PCT can be detected in serum, and peak level is usually soon released. It has been confirmed that PCT can serve as an effective indicator for diagnosis of infection in critical patients and to monitor the management of sepsis. An increasing in PCT can be detected in severe sepsis and septic shock ${ }^{20-22}$. PCT is not released in the presence of noninfectious inflammation or localized infection ${ }^{22}$. In fact, in the present study, we observed that PCT had very high serum levels in rats with sepsis and that the association of pneumoperitoneum with sepsis resulted in a significant decrease in PCT levels.

Significant prevalence of high concentrations of CRP in critically ill patients has been described ${ }^{23}$. In this study, the association of pneumoperitoneum in animals with abdominal sepsis by CLP contributed to the decrease in serum CRP levels, compared to the group without pneumoperitoneum, meaning that the peumoperitoneum with $\mathrm{CO}_{2}$ exerted a reducing effect on the expression of sepsis biomarkers such as CRP and proinflammatory cytokines. In the present study, the finding of a lower CRP serum levels in the abdominal sepsis $+\mathrm{CO}_{2}$ pneumoperitoneum group than in the sepsis group showed that $\mathrm{CO}_{2}$ pneumoperitoneum contributed to decreasing the acute phase inflammatory response against sepsis. Corroborating our results, Are et al demonstrated similar findings ${ }^{24}$.

It has been stated that $\mathrm{CO}_{2}$ pneumoperitoneum may cause elevated hypercapnia and toxic shock syndrome in cases with abdominal sepsis ${ }^{25}$. However, it has also been demonstrated that pneumoperitoneum has no impact on the systemic dissemination of abdominal sepsis and that laparoscopic surgery preserves peritoneal defense mechanisms ${ }^{26}$. In conclusion, $\mathrm{CO}_{2}$ pneumoperitoniun attenuates the biomarkers of acute phase inflammatory response associated with perioperative CLP sepsis.

\section{REFERENCES}

1. Singer M, Deutschman CS, Seymour CW, Shankar-Hari M, Annane D, et al. The third international consensus definitions for sepsis and septic shock (Sepsis3) JAMA. 2016;315:801-10.

2. Fleischmann C, Scherag A, Adhikari NK, Hartog CS, Tsaganos T, Schlattmann P, Angus DC, Reinhart K International Forum of Acute Care Trialists. Assessment of global incidence and mortality of hospital-treated sepsis. Current estimates and limitations. Am J Respir Crit Care Med. 2016;193:259-72.

3. van der Poll T, Opal SM. Host-pathogen interactions in sepsis. Lancet Infect Dis. 2008;8:32-43.

4. Andersson U, Tracey KJ. Reflex principles of immunological homeostasis. Annu Rev Immunol. 2012;30:313-35.

5. Boomer JS, To K, Chang KC, et al. Immunosuppression in patients who die of sepsis and multiple organ failure. JAMA 2011;306:2594-605. 
Effect of pneumoperitoneum in model of abdominal sepsis

Silva $C D$, et al

6. Torgersen $\mathrm{C}$, Moser $\mathrm{P}$, Luckner $\mathrm{G}$, et al. Macroscopic postmortem findings in 235 surgical intensive care patients with sepsis. Anesth Analg. 2009;108:1841-7.

7. Larsen FF, Petersen JA. Novel biomarkers for sepsis: A narrative review. Eur J Intern Med. 2017;45:46-50.

8. Faix JD. Biomarkers of sepsis. Crit Rev Clin Lab Sci. 2013;50:23-36.

9. Hanly E J, Fuentes J M, Aurora A R, et al. Carbon dioxide pneumoperitoneum prevents mortality from sepsis. Surg Endosc Other Interv Tech. 2006;20:1482-7.

10. Metzelder M, Kuebler J Shimotakahara FA, Chang DH, Vieten C, Ure B. CO2 neumoperitoneum increases survival in mice with polymicrobial peritonitis. Eur J Ped Surg, 2008;18(3):171-5.

11. Chatzimavroudis G, Pavlidis T E, Koutelidakis I, et al., CO2 pneumoperitoneum prolongs survival in an animal model of peritonitis compared to laparotomy. J Surg Res. 2009;152(1):69-75.

12. Azevedo ÍM, Carvalho MD, Nascimento RP, Macedo R, Aquino MR, Medeiros AC.Anatomo-radiological correlation using 18-FDG-PET in abdominal sepsis model in rats. A preliminary study. Acta Cir Bras. 2017;32(3):175-81.

13. Medeiros VF, Azevedo ÍM, Carvalho MD, Egito ES, Medeiros AC. Effects of cococonut water and simvastatin in the treatment of sepsis and hemorrhagic shock in rats. Acta Cir Bras. 2016;31(12):826-33.

14. Macedo R, Javadi SM, Higuchi T, Carvalho MD, Medeiros Vde F, Azevedo ÍM, Lima FP, Medeiros AC. Heart and systemic effects of statin pretreatment in a rat model of abdominal sepsis. Assessment by Tc99m-sestamibi biodistribition. Acta Cir Bras. 2015;30(6):388-93.

15. Delong P, Murray JA, Cook CK. Mechanical ventilation in the management of acute respiratory distress syndrome. Semin Dial. 2006;19:517-24.

16. Galley HF. Oxidative stress and mitochondrial dysfunction in sepsis. $\mathrm{Br} \mathrm{J}$ Anaesth. 2011;107:57-64.

17. Wang YT, Fu JJ, Li XL, Li YR, Li CF, Zhou CY. Effects of hemodialysis and hemoperfusion on inflammatory factors and nuclear transcription factors in peripheral blood cell of multiple organ dysfunction syndrome. Eur Rev Med Pharmacol Sci. 2016;20:745-50.

18. Xie C, Kang J, Ferguson ME, Nagarajan S, Badger TM, Wu X. Blueberries reduce proinflammatory cytokine TNF- $\alpha$ and IL-6 production in mouse macrophages by inhibiting NF-KB activation and the MAPK pathway. Mol Nutr Food Res. 2011;55:1587-91.

19. Standage SW and Wong HR: Biomarkers for pediatric sepsis and septic shock. Expert Rev Anti Infect Ther. 2011;9:71-9. 
Effect of pneumoperitoneum in model of abdominal sepsis

Silva $C D$, et al

20. Deng Y, Yang Z, Gao Y, Xu H, Zheng B, Jiang M, Xu J, He Z, Wang X. Toll-like receptor 4 mediates acute lung injury induced by high mobility group box-1. PLoS One. 2013;8:e64375. doi: 10.1371/journal.pone.0064375.

21. Povoa P, Coelho L, Almeida E, Fernandes A, Mealha R, Moreira P, Sabino H. Creactive protein as a marker of infection in critically ill patients. Clin Microbiol Infect. 2005;11(2):101-8.

22. Christ-Crain M, Jaccard-Stolz D, Bingisser R, Gencay MM, Huber PR, Tamm M, Müller B. Effect of procalcitonin-guided treatment on antibiotic use and outcome in lower respiratory tract infections: cluster-randomised, single-blinded intervention trial. Lancet. 2004;363(9409):600-7.

23. Lobo SM, Lobo FR, Bota DP, Lopes-Ferreira F, Soliman HM, Vincent JL. C-reactive protein levels correlate with mortality and organ failure in critically ill patients. Chest. 2003;123(3):2043-9.

24. Are C, Talamini MA, Murata K, De Maio A. Carbon dioxide pneumoperitoneum alters acute-phase response induced by lipopolysaccharide. Surg Endosc. 2002;16:14647.

25. Diebel LN, Dulchavsky SA, Wilson RF. Effect of increased intra-abdominal pressure on mesenteric arterial and intestinal mucosal blood flow. J Trauma. 1992;33:45-9.

26. Collet e Silva FD, Ramos RC, Zantut LF, Poggetti RS, Fontes B, Birolini D. Laparoscopic pneumoperitoneum in acute peritonitis does not increase bacteremia or aggravate metabolic or hemodynamic disturbances. Surg Laparosc Endosc Percutan Tech 2000;10:305-10. 